\title{
MICROSTRUCTURAL EVOLUTION AND MATERIALS FLOW IN BUTT COLD WELDING OF COPPER
}

\author{
MIKROSTRUKTURNI RAZVOJ IN PLASTIČNO TEČENJE \\ MATERIALA MED HLADNIM ČELNIM VARJENJEM BAKRA
}

\author{
Yong Huang ${ }^{1,2 *}$, Xiao-Juan Yan ${ }^{1}$, Xiao-Long $\operatorname{Ran}^{1}$ \\ ${ }^{1}$ Lanzhou University of Technology, State Key Laboratory of Advanced Processing and Recycling of Nonferrous Metals, \\ No. 287, Langongping Road, Qilihe District, Lanzhou 730050, Gansu, China \\ ${ }^{2}$ Lanzhou University of Technology, School of Materials Science and Engineering, Lanzhou 730050, China
}

Prejem rokopisa - received:2019-11-27 ; sprejem za objavo - accepted for publication: 2020-07-27

doi:10.17222/mit.2019.286

\begin{abstract}
In this study, deformation behavior and microstructure evolution of pure copper during butt cold welding were investigated. The relationship between the strain during bonding and the corresponding microstructure evolution was discussed. A finite-element model (FEM) of butt cold welding was established to explore the relationship between the strain and metal bonding. The strain in the extrusion centre line reaches a value of 2.6 , at which bonding starts to occur in this material. An electron-backscatterdiffraction (EBSD) analysis and optical microscopy were conducted in the corresponding regions and the microstructural evolution with the strain was examined. Further study of the microscopic evolution revealed that the DRX degree was significantly improved with the increase in the strain, indicating that recrystallization plays a very important role in copper cold welding.
\end{abstract}

Keywords: copper, butt cold welding, finite-element simulation, deformation behavior, microstructure evolution

V članku avtorji opisujejo raziskavo deformacijskega obnašanja in razvoja mikrostrukture čistega bakra med hladnim čelnim varjenjem. Obravnavali so deformacijo nastalo med spajanjem (varjenjem) in ustreznim razvojem mikrostrukture. Izdelali so model hladnega čelnega varjenja na osnovi metode končnih elementov (FEM) zato, da so lahko raziskovali povezavo med deformacijo in spajanje dveh kosov bakra med njunim hladnim zvarjanjem. Deformacija v središčni liniji čelnega zvara pri kateri je nastopilo spajanje materiala je dosegla vrednost 2,6 . Z analizo na osnovi povratno sipanih elektronov (EBSD) in Z optično mikroskopijo so v karakterističnih področjih zvara raziskovali razvoj mikrostrukture in deformacijo. Nadaljnji študij razvoja mikrostrukture je pokazal stopnjo dinamične rekristalizacije (DRX) in da se le ta močno izboljša z naraščanjem deformacije. To kaže na to, da rekristalizacija igra pomembno vlogo med hladnim varjenjem bakra.

Ključne besede: baker, čelno varjenje, simulacija na osnovi metode končnih elementov, deformacijsko vedenje, razvoj mikrostrukture

\section{INTRODUCTION}

Copper plays an extremely significant role in many industry areas, such as electronic vehicle and nuclear industries, due to its excellent thermal conductivity and favorable combination of strength and ductility. As they are conducting materials in many applications, high electrical conductivity and high mechanical strength are often required simultaneously. ${ }^{1}$ In this context, the solid-state process (SSP) offers an ideal basis for application in such structures with no fusion zone and no heat-affected zone (HAZ). ${ }^{2}$ This process has been shown suitable for joining a variety of materials with similar or dissimilar configurations. Cold pressure welding (CPW) is one type of the SSP, mainly carried out in two basic variants: spot welding and butt welding. A butt-welding process involves surface expansion only, and the bonding starts with the formation of small cracks in the oxide layer during plastic deformation and proceeds with the

*Corresponding author's e-mail: hyorhot@lut.cn (Yong Huang) extrusion of the underlying oxide-free metal through the cracks.

On the other hand, in cold pressure welding, the surface oxide is continuously removed during the compression due to the upset collar formation. ${ }^{3}$ There are several theories of the weld formation in CPW, which mainly include metallurgical adhesion derived from a significant amount of plastic deformation, diffusion across the weld interface, local melting, mechanical interlocking and dynamic recrystallization. ${ }^{4}$ For similarmaterial joints, dynamic recrystallization (DRX) was found to be the main bonding mechanism. In the case of dissimilar materials, diffusion promotes the solid-solution strengthening phase at the weld interface. ${ }^{5}$ There has been a considerable research effort aiming at understanding the origin of recrystallization. The importance of recrystallization nucleation is that it is a crucial factor in determining both the size and orientation of the resulting grains. Strain-induced grain-boundary migration (SIBM) is a dominating mechanism, and it has been observed in a wide variety of metals. SIBM involves the bulging of part of the pre-existing grain boundary, 
creating a region with a lower dislocation content behind the migrating boundary. ${ }^{6}$

Severe plastic deformation and high temperature (higher than the recrystallization temperature) may cause the formation of new crystalline structures at the interface. ${ }^{7}$ DRX can occur in the continuous or discontinuous mode depending on the material and deformation mode. A continuous process involves the rotation of subgrains, which can be observed simultaneously in the entire microstructure, whereas discontinuous dynamic recrystallization (DDRX) involves an inhomogeneous nucleation step followed by the growth of recrystallized grains due to high-angle grain-boundary (HAGB) migration. Moreover, continuous dynamic recrystallization (CDRX) is associated with a low stacking-fault energy (SFE) due to an easier cross slip and recovery, whereas a high SFE typically results in a discontinuous process. Under the shear or shear-compression state, DRX occurs locally through a mechanism similar to the continuous process described above, involving the formation of elongated subgrains or bands, which subsequently break up into an equiaxed structure with the local rotation of subgrain boundaries. This also takes place in medium to high SFE materials such as copper, due to the localization of plastic deformation into shear bands resulting from the adiabatic heating and/or geometrical constraints. ${ }^{8}$

It was reported that bonding does not occur until a certain threshold deformation is reached. After reaching this threshold, depending on the metal combination, the bonding strength increases rapidly with the degree of deformation and reaches a plateau corresponding to the strength of the base metal.9,10 This mechanism was confirmed $^{11,12}$ with scanning-electron-microscopy (SEM) studies of a fractured welding surface by different researchers. It was found that the surface preparation before cold welding is an important parameter, governing the weld formation. ${ }^{13}$ It was also found that the welding quality is determined by the metal-flow behavior, solid-state bonding process and microstructural evolution. ${ }^{14}$

Consequently, it is of great significance to understand the parametric conditions, under which cold bonding takes place during the divergent extrusion of butt cold welding $(\mathrm{BCW})$ of copper. In the present investigation, the divergent extrusion of butt cold welding of pure copper was further discussed and explored to reveal the conditions under which cold bonding takes place. Macro- and microscopic analyses, and FE modeling were jointly used to reveal the details of the material-flow pattern and deformation mode at the mating interfaces during bonding, and establish a simple strainbased criterion for metallic bonding. Furthermore, the corresponding microstructure evolution was discussed and results of the macroscopic analysis were provided to validate the FE modeling.

\section{EXPERIMENTAL PART}

Commercially pure copper (T2) rods with a purity of $99.9 \%$, a diameter of $8.0 \mathrm{~mm}$ and a length of $18 \mathrm{~mm}$ were prepared for bonding with butt cold welding at room temperature, using a die as shown in Figure 1. These welding experiments were carried out using a YT100 four-column press with a speed of $10 \mathrm{~mm} / \mathrm{s}$. All the experiment specimens were degreased and scratchbrushed using a kind of efficient surface-preparation $\operatorname{method}^{9,15}$ prior to welding. After the surface preparation, handling of these rods was performed carefully to avoid renewed contamination. The time between the surface preparation and compression was kept to less than $120 \mathrm{~s}$ to avoid the formation of a thick and continuous oxide layer on the bonding surfaces of these rods.

Following the BCW process, a 1-mm welding gap between the two positioning moulds is ensured. The samples for the microstructural examination were prepared by slicing the rods perpendicular to the extrusion direction into $\approx 2.0$-mm-thick slices, and then mechanically polished until a mirror-like surface was achieved. Finally, those slices were electro-polished for 6-8 min in a solution of $50 \%$ distilled water, $25 \%$ phosphoric acid and $25 \%$ alcohol, using the $4-\mathrm{V}$ polishing voltage. Electron-backscatter-diffraction (EBSD) measurements were taken using a Quanta FEG-450 high-resolution scanning-electron microscope (SEM) equipped with a field-emission cathode. EBSD maps were obtained with HKL (Oxford Instruments) software package Channel 5. A representative set of copper rods joined with $\mathrm{BCW}$ were cleaned and ground to remove at least $1 \mathrm{~mm}$ of the outermost material to reveal the underlying bulk-material flow pattern. The specimens were subsequently incrementally polished until the surface roughness reached $3 \mu \mathrm{m}$ and then anodized. The grain-deformation structure was studied with an Axio Scope A1 optical microscope. The pictures were taken at a low magnification of $50 \times$ to reveal the entire material flow pattern within the deformation zone.

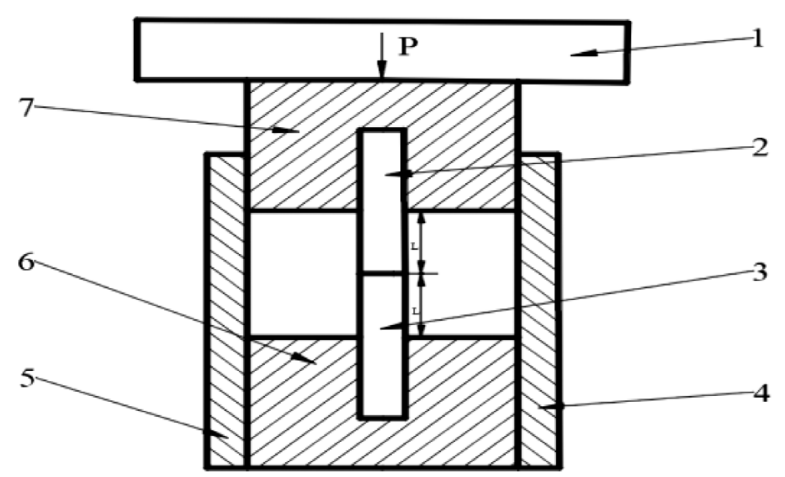

Figure 1: Schematic diagram of the butt-cold-welding mold: 1 - hydraulic-press head; 2, 3 - copper rod; 4, 5 - fixed mold base; 6,7 - positioning molds 


\section{RESULTS AND DISCUSSION}

\subsection{Finite-element analysis and simulation set-up}

Finite-element (FE) modelling was used to reveal the conditions, under which cold bonding takes place during the divergent extrusion of a $\mathrm{BCW}$ process, and the conditions were determined with the underlying-material flow pattern and deformation mode within the die region. The simulations were conducted using the commercial metal-forming FE code ANSYS WORKBENCH. Deformation was the controlling parameter for cold welding. In order to save the computation time, an axial symmetric 2D model and the modelling domain of a half specimen were employed. Figures $\mathbf{2 a}$ and $\mathbf{2 b}$ show the two copper-rod configurations in FEM before and after the deformation, respectively, and Figure 2C shows a detail of the modelling with the finite-element method. In the simulations, the die was treated as the rigid isothermal object, while the copper rod was modelled as the plastic workpiece. They were adequately represented by a homogenous friction coefficient acting on the mould surfaces. The interaction between the two copper rods was also fully expressed by a uniform friction coefficient, which was set to $0.18 .{ }^{16}$ Since the material testing was done at room temperature to comply with the cold-extrusion experiments, the strain-rate dependence of the flow stress was rather weak. Relevant material parameters from the database were used for the calculation in the simulations.

\subsection{Predicted strain distributions during divergent extrusion}

Figures 3 summarizes the $\mathrm{FE}$ simulation results of the divergent-extrusion process of BCW. In Figure 3a, the left-hand side shows a picture of the physical specimen after $\mathrm{BCW}$, while the right-hand side shows

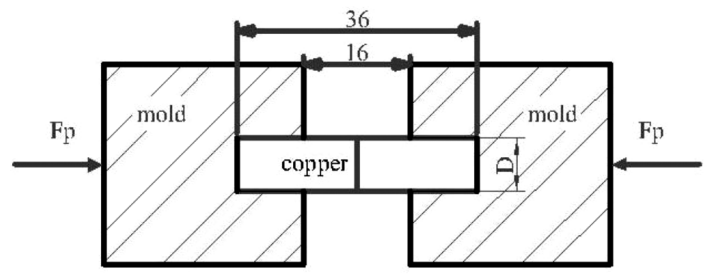

A

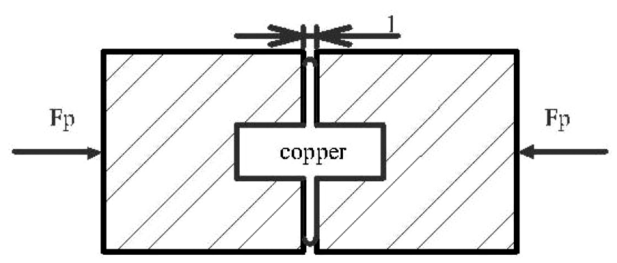

B the simulated effective strain distribution within the two-rod specimen being extruded with a 1-mm welding gap. There is no noticeable difference between these two parts. The separating interface between the copper rods to be welded is still presented in the central region, while no clear interface exists in the fin region, as clearly shown in Figure 3a. This is due to the fact that the plastic flow in the central region is constrained.

Figure $\mathbf{3 b}$ is a locally enlarged view of the material flow pattern at the position of the arrow in Figure 3a. These results provide a good overall view of the intersecting shear-deformation bands formed during the extrusions. In the shear-deformation zone, the material is subjected to extensive plastic deformation, forming two intersecting bands being orientated $\pm 45^{\circ}$ with respect to the longitudinal axis of the extrusion channels. However, at the centre of the intersection of the deformation zone, we can see that the degree of deformation is low.

Two different deformation modes that the material undergoes during the divergent extrusion are further highlighted in Figures 3. The rod of the workpiece experiences a homogenous shear deformation and the narrow zone towards the centre line is subjected to the plane-strain compression in the primary-extrusion direction. The resulting squeezing of the material in the horizontal direction contributes to a large surface expansion, consequently providing the necessary conditions for cold welding. Note that the surface expansion is also required in the cases where two oxide-free surfaces are allowed to mate under pressure, as is the case during divergent extrusion. ${ }^{3}$

Part A of Figure 4 shows an optical-microscope image of the welded specimen, while the snapshot of the resulting effective strain distribution is provided in part B. When comparing them, it becomes clear that the metals in the elliptical area, indicated by the arrow, were joined where the macroscopically effective strain

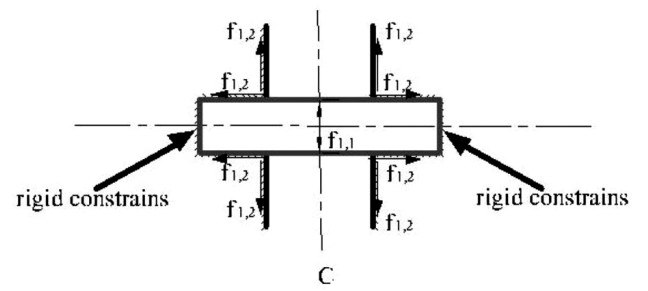

Figure 2: A, B - a sketch of butt cold welding; $\mathrm{C}$ - details of modelling with the finite-element method, $f_{1,2}=$ coefficient of friction in the die, $f_{1,1}$ $=$ coefficient of friction between the two copper rods 
exceeded 2.6 and reached 2.9, which is similar to the numerical simulation of divergent extrusion under the conditions of cold-pressure welding of commercially pure aluminium. ${ }^{17}$ In that study, when the effective strain at the centre line on the two mating surfaces was high enough, reaching 3.0, the essential conditions for cold bonding were met.
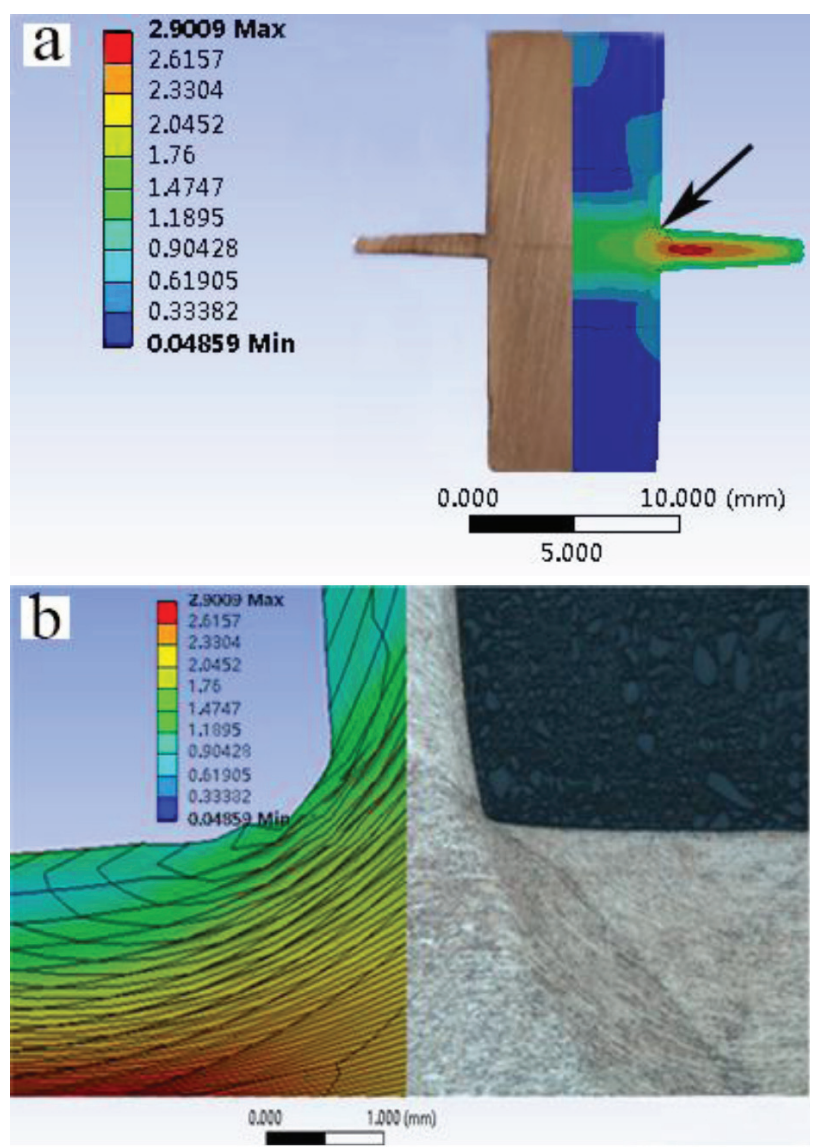

Figure 3: a) snapshots showing the two-bar specimen being extruded with a 1-mm welding gap, left - result of the experiment, right - result of the FE model; b) partially enlarged view of the material flow pattern at the position of the arrow, left - result of the FE model, right - photograph taken with the optical microscope

\subsection{Microstructure evolution}

The bonding between the two rods was believed to be related to the strains and microstructure evolution in the material. In order to find these relationships, microstructures from different regions of the welded specimen were investigated through an EBSD analysis. The EBSD scanned areas are shown in Figure 5 and the corresponding results are given in Figures 6 to 8. As shown in Figure 5, zone $a$ is subjected to a low strain, zone $b$ is in

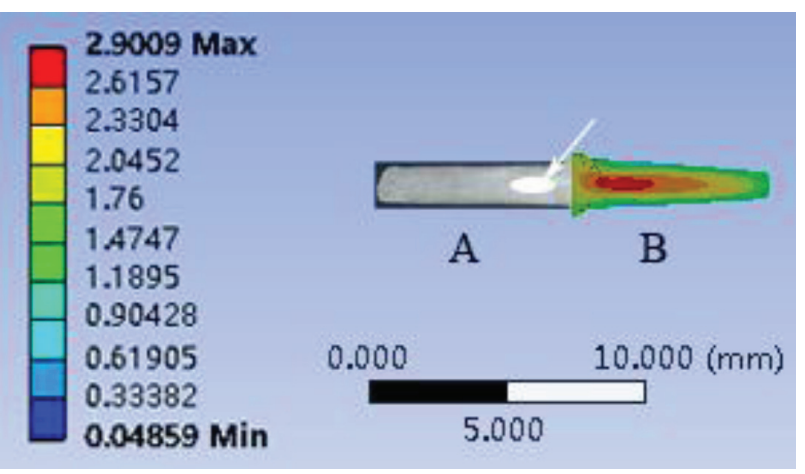

Figure 4: Snapshots showing the fin after extrusion with a 1-mm welding gap, A - photograph taken by the optical microscope, the elliptical area indicated by the arrow is the area where the connection takes place, B - strain-distribution result of the FE model

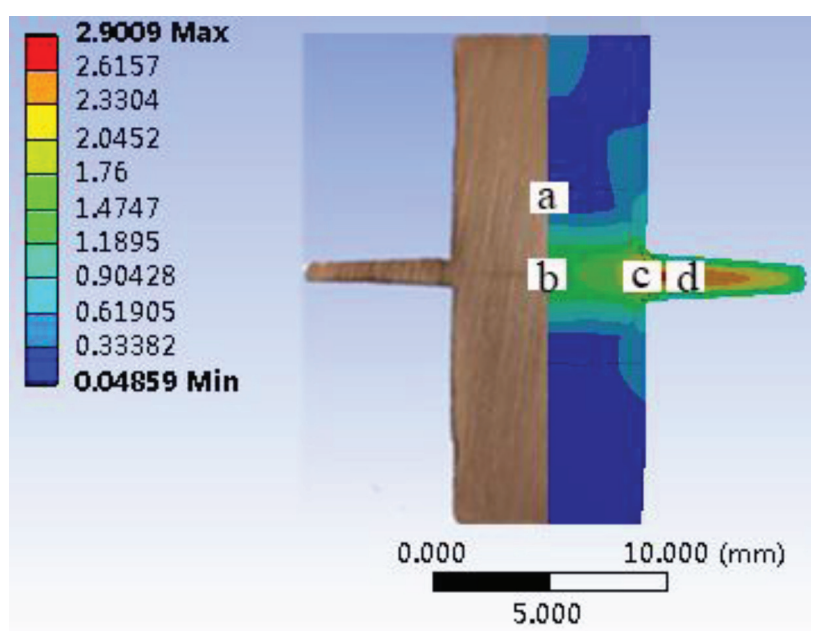

Figure 5: Electron-backscatter-diffraction (EBSD) sampling positions and scanned areas
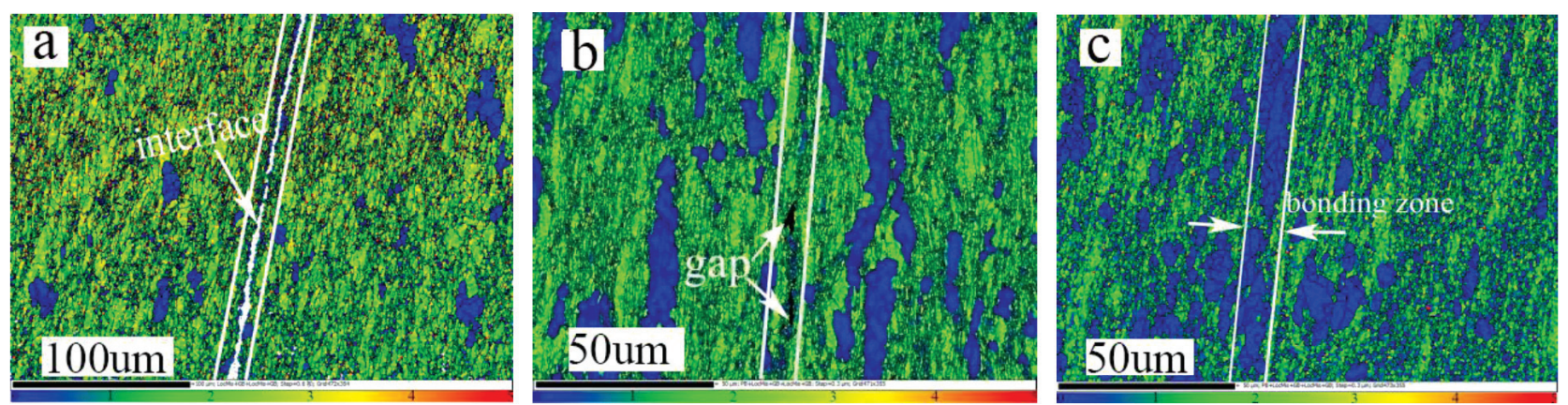

Figure 6: Local-misorientation mapping of the specimens from the centre line: a) centre of the sample, b) connection-boundary area, c) joint zone 
the welding center with a medium strain, and zones $c$ and $d$ are in the region of a high strain along the original mating surfaces. It should be noted that only half of zone $c$ is in the high-strain region.

It is commonly recognized that dislocation densities are almost uniformly distributed at the initial stages of plastic deformation of polycrystalline materials. However, the mismatch of the slips at grain boundaries or intragranular regions results in the gradients of plastic strain with the increase of deformation, which subsequently results in the formation of geometrically necessary dislocations (GNDs) of the compatible deformations of different parts of the grains. ${ }^{18,19}$ Figure 6 shows the local-misorientation mapping of the specimens from the centre line. It can be clearly seen on the figure that the fraction of the blue zone in the interface area between the two white lines is increased with the increase in the strain, indicating an increased dynamic recrystallization with fewer low-angle grain boundaries (LABs) under a relatively high strain. As shown in Figures $6 \mathbf{a}$ to $\mathbf{6 c}$, no bonding occurs in the centre of the interface with the low DRX degree, while it occurs in the centre of the interface with a high DRX degree. This indicates that recrystallization plays a very important role in copper cold welding.

Figure 7 shows grain/sub grain boundary (GSB) maps with different deformation strains corresponding to different positions. In these GSB maps, the black and green lines represent high-angle grain boundaries (HAGBs) and low-angle grain boundaries (LAGBs), respectively. In this study, the grain boundaries in the deformed microstructure are categorized as the following two types: low-angle boundaries (LABs) and high-angle grain boundaries (HABs). LABs are defined as the boundaries having a misorientation angle of less than $15^{\circ}$, while HABs are considered as the boundaries having a misorientation angle of more than $15^{\circ} .^{20}$

As shown in Figure 8, it can be easily found that the fraction of LABs greatly decreases with the increase in

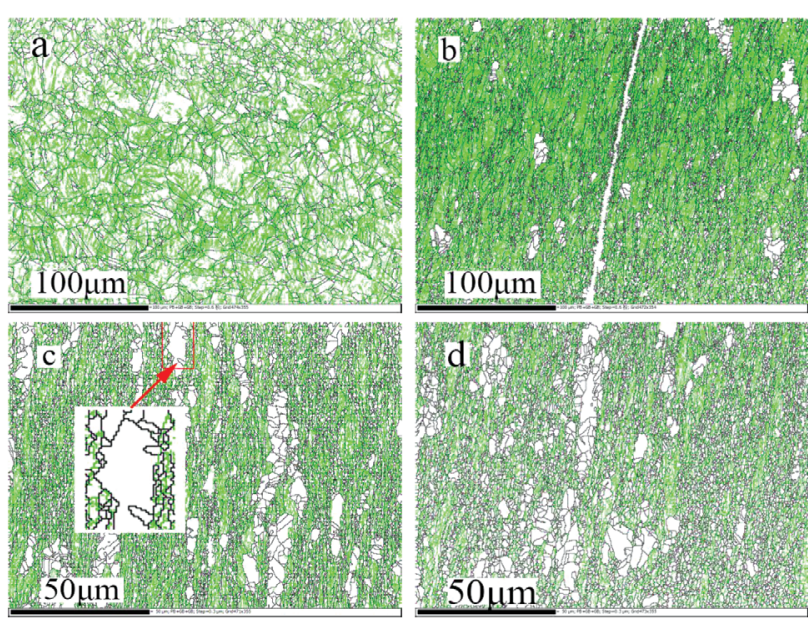

Figure 7: Grain boundaries (black HABs and green LABs) in the specimens under different conditions the strain. This means that the increased number of recrystallized grains are under a relatively high strain. New fine grains evolve with further deformation under lower strains, while coarse grains with high angles still exist. As shown in Figure 7a, large primary grains are not significantly reduced and low grain boundaries are inhomogeneously developed, accompanied by embryos of dislocation substructures. When moderate strains appear, an extension of large grains can be observed, accompanied by a large deformation and large amounts of the subgrain structure inside the grains. Grains with high misorientations are elongated in the freeform-deformation $(x)$ direction, which is vertical to the pressing direction. A weak fibrous microstructure consisting of small deformation bands is thus found aligned to the pressing direction. Although the percentage of LAGBs is reduced, the practical amount of grains in this type is increased. The recrystallized grains may be generated due to the combining effect of severe plastic deformation and local heating. New fine grains with low-angle dislocation sub-grain boundaries are homogeneously developed in the deformed HAGB grain interiors (as shown Figures $\mathbf{7 a}$ and $\mathbf{7 b}$ ).

When higher strains appear, we can see that the volume fraction of dynamic-recrystallization (DRX) grains is increased with the increase in the strains, indicating that the DRX behavior occurs easily at higher strains. Obviously, the microstructure evolution is closely related to strains. In general, DDRX is relevant for the bulging mechanism operating in the materials with low or medium stacking-fault energy, involving the nucleation of new grains and a subsequent grain growth. CDRX is considered as a recovery process and proceeded by continuous absorption of dislocations in subgrain boundaries, which results in the formation of high-angle boundaries and new grains. It is found that the DRX of the original grain boundaries becomes serrated and bulging, as shown in the partially enlarged view on Figure 7c, indicating the initiation of DRX owing to the strain-induced boundary migration. Meanwhile, a few dynamically recrystallized grains are also

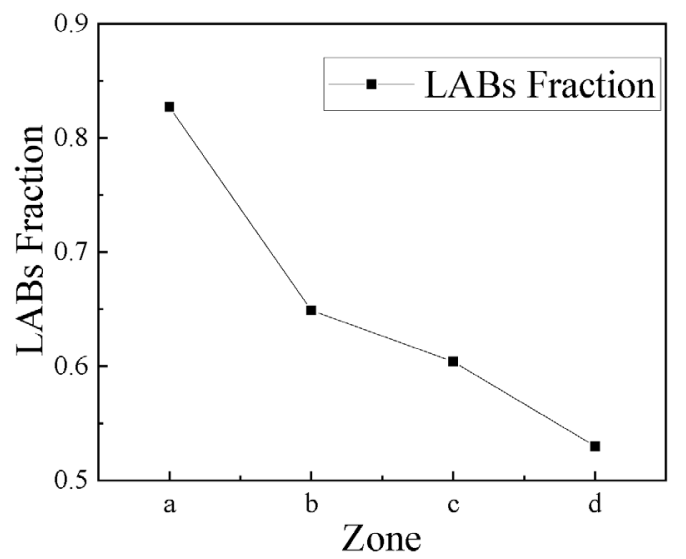

Figure 8: LAB-fraction evolution in the specimens under different conditions 

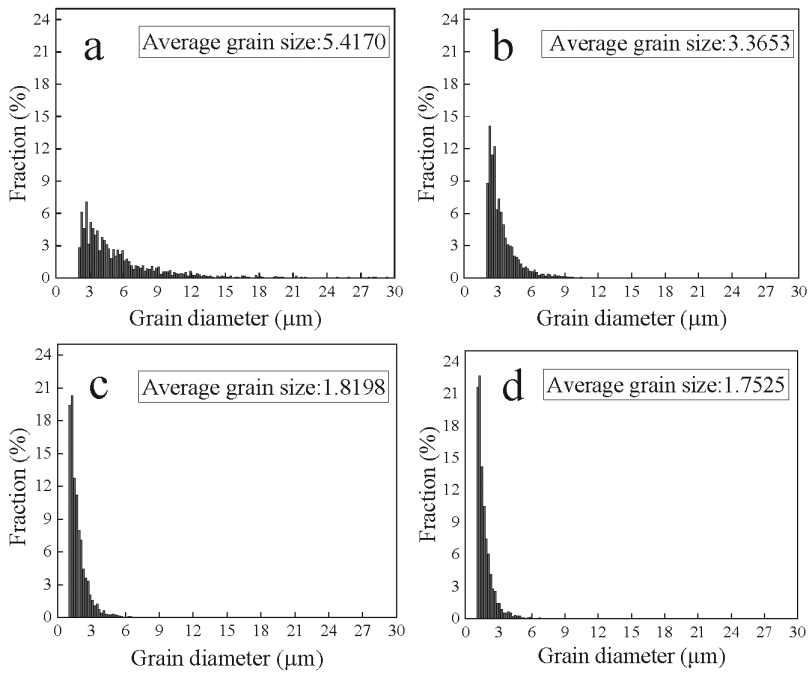

Figure 9: Grain-diameter distribution in the specimens under different conditions

observed along the grain boundaries (as shown in Figures $7 \mathrm{c}$ and $\mathbf{7 d}$ ).

Lilleby et al. observed divergent extrusion of commercially pure aluminum. According to the previous finite-element (FE) simulations, ${ }^{17}$ it was easy to confirm that the increase in the maximum temperature due to plastic deformation is about $110{ }^{\circ} \mathrm{C}$, assuming adiabatic conditions. However, the real temperature increase is much lower and does not exceed $20^{\circ} \mathrm{C}$ because of the heat conduction in the aluminum billet and the surrounding tool steel. Yang et al. studied the effect of cold-rolling deformation-induced heat on the interfacial bonding strength. Their results revealed that deformation-induced localized heating in low-thermal-conductivity metal multilayer systems may provide opportunities for achieving successful accumulative roll bonding. ${ }^{21}$ Since the temperatures of the specimens were below $50{ }^{\circ} \mathrm{C}$, dynamic recrystallization occurred at a relatively low temperature and the DRX grain size changed little with the increasing strains, which was mainly related to the lower mobility of DRX grain boundaries at the lower deformation temperature. ${ }^{22-25}$

Figure 9 shows the grain-size distribution in the specimens under different conditions. As can be seen, grain sizes become gradually smaller with the increased strains. The average grain sizes were found to be reduced from $5.4170 \mu \mathrm{m}$ to $1.7525 \mu \mathrm{m}$, as shown in Figures 9 a to 9d, indicating a grain-refinement strengthening effect. ${ }^{26}$ However, as shown in Figures 9c and 9d, the grain size changes little and this is believed to be caused by dynamic recrystallization, which is consistent with the increase in the volume fraction of DRX grains as the strain increases.

\section{CONCLUSIONS}

The butt-cold-welding bonding occurs in the fin region because the metal flow in the central region is constrained. Based on the developed FEM model, a cold-welding-process interpretation was achieved by establishing the correlation between the strain distribution and metal connection. When the macro-effective strain exceeds a value of about 2.6, the interface is welded.

Comparing the three different areas of the center line, the fact that the metal connection occurs at a higher strain can be confirmed. Further study of the microscopic evolution reveals that the DRX degree is significantly improved with the increasing strain, indicating that recrystallization plays a very important role in copper cold welding.

As the value of strain increases, a large number of dynamically recrystallized grains begin to appear around the original grain boundaries, gradually replacing the original deformed grains, resulting in an increase in the volume fraction of dynamic recrystallization. Owing to the inadequate temperature, the size of dynamically recrystallized grains presents an insensible change with the subsequently increased strain.

\section{REFERENCES}

${ }^{1}$ J. Ning, L. J. Zhang, A. Wang, Q. L. Bai, J. N. Yang, J. X. Zhang, Effects of double-pass welding and extrusion on properties of fiber laser welded 1.5-mm thick T2 copper joints, Journal of Materials Processing Technology, 237 (2016), 75-87, doi:10.1016/j.jmatprotec. 2016.06.011

${ }^{2}$ R. Kocich, A. Macháčková, L. Kunčická, F. Fojtík, Fabrication and characterization of cold-swaged multilayered Al-Cu clad composites, Materials and Design, 71 (2015), 36-47, doi:10.1016/j.matdes. 2015.01.008

${ }^{3}$ A. Lilleby, Ø. Grong, H. Hemmer, T. Erlien, Experimental and finite element studies of the divergent extrusion process under conditions applicable to cold pressure welding of commercial purity aluminium, Materials Science and Engineering: A, 518 (2009) 1-2, 76-83, doi:10.1016/j.msea.2009.04.021

${ }^{4}$ S. Shawn Lee, T. Hyung Kim, S. Jack Hu, W. W. Cai, J. A. Abell, J. J. Li, Characterization of joint quality in ultrasonic welding of battery tabs, Journal of Manufacturing Science and Engineering, 135 (2013) 2, 021004, doi:10.1115/1.4023364

${ }^{5}$ G. A. Pinheiro, C. A. W. Olea, J. F. dos Santos, K. U. Kainer, Microstructural and mechanical behavior of friction welds in a high creep resistance magnesium alloy, Advanced Engineering Materials, 9 (2007) 9, 757-763, doi:10.1002/adem.200700159

${ }^{6}$ F. J. Humphreys, M. Hatherly, Recrystallization and related annealing phenomena, Elsevier, UK 2012, 254-259

${ }^{7}$ W. Cai, G. Daehn, A. Vivek, J. J. Li, H. Khan, R. S. Mishra, M. Komarasamy, A state-of-the-art review on solid-state metal joining, Journal of Manufacturing Science and Engineering, 141 (2019) 3, 031012, doi:10.1115/1.4041182

${ }^{8}$ N. Mortazavi, N. Bonora, A. Ruggiero, M. Hörnqvist Colliander, Dynamic recrystallization during high-strain-rate tension of copper, Metallurgical and Materials Transactions A, 47 (2016) 6, 2555-2559, doi:10.1007/s11661-016-3491-x

${ }^{9}$ S. A. Hosseini, M. Hosseini, H. Danesh Manesh, Bond strength evaluation of roll bonded bi-layer copper alloy strips in different rolling conditions, Materials and Design, 32 (2011) 1, 76-81, doi:10.1016/j.matdes.2010.06.032 


\section{Y. HUANG et al.: MICROSTRUCTURAL EVOLUTION AND MATERIALS FLOW IN BUTT COLD WELDING OF COPPER}

${ }^{10}$ H. C. Schmidt, D. Rodman, O. Grydin, C. Ebbert, W. Homberg, H. J. Maier, G. Grundmeier, Joining with electrochemical support: Cold pressure welding of copper - weld formation and characterization, Advanced Materials Research, 966-967 (2014), 453-460, doi:10.4028/www.scientific.net/AMR.966-967.453

${ }^{11}$ S. Zenitani, N. Hayakawa, J. Yamamoto, K. Hiraoka, Y. Morikage, T. Kubo, K. Yasuda, K. Amano, Development of new low transformation temperature welding consumable to prevent cold cracking in high strength steel welds, Science and Technology of Welding and Joining, 12 (2013) 6, 516-522, doi:10.1179/174329307x213675

${ }^{12}$ M. Eizadjou, H. Danesh Manesh, K. Janghorban, Investigation of roll bonding between aluminum alloy strips, Materials and Design, 29 (2008) 4, 909-913, doi:10.1016/j.matdes.2007.03.020

${ }^{13}$ B. W. Zhang, N. Bay, Cold welding - experimental investigation of the surface preparation methods, Welding Journal, 76 (1997) 8 , 326-330

${ }^{14}$ J. Q. Yu, G. Q. Zhao, Study on the welding quality in the porthole die extrusion process of aluminum alloy profiles, Procedia Engineering, 207 (2017), 401-406, doi:10.1016/j.proeng.2017.10.795

${ }^{15} \mathrm{M}$. Sahin, Effect of surface roughness on weldability in aluminium sheets joined by cold pressure welding, Industrial Lubrication and Tribology, 60 (2008) 5, 249-254, doi:10.1108/00368790810895187

${ }^{16}$ C. D. Tian, D. Tang, D. Y. Li, Y. H. Peng, A testing method of friction coefficient and its application in numerical simulation, Journal of Plasticity Engineering, 15 (2008) 5, 53-56, 61, (Chinese)

${ }^{17}$ A. Lilleby, $\varnothing$. Grong, H. Hemmer, Experimental and finite element simulations of cold pressure welding of aluminium by divergent extrusion, Materials Science and Engineering: A, 527 (2009) 1-2, 179-186, doi:10.1016/j.msea.2009.07.051

${ }^{18}$ O. Rezvanian, M. A. Zikry, A. M. Rajendran, Statistically stored, geometrically necessary and grain boundary dislocation densities: Microstructural representation and modelling, Proceedings of the Royal Society A: Mathematical, Physical and Engineering Sciences, 463 (2007) 2087, 2833-2853, doi:10.1098/rspa.2007.0020

${ }^{19}$ Y. C. Lin, D. G. He, M. S. Chen, X. M. Chen, C. Y. Zhao, X. Ma, Z. L. Long, EBSD analysis of evolution of dynamic recrystallization grains and $\delta$ phase in a nickel-based superalloy during hot compressive deformation, Materials \& Design, 97 (2016), 13-24, doi:10.1016/j.matdes.2016.02.052
${ }^{20}$ S. Saadatkia, H. Mirzadeh, M. J. M. Cabrera, Hot deformation behavior, dynamic recrystallization, and physically-based constitutive modeling of plain carbon steels, Materials Science \& Engineering A, 636 (2015), 196-202, doi:10.1016/j.msea.2015. 03.104

${ }^{21}$ D. Yang, K, J. Y. Xiong, P. Hodgson, C. e. Wen, Influence of deformation-induced heating on the bond strength of rolled metal multilayers, Materials Letters, 63 (2009) 27, 2300-2302, doi:10.1016/ j.matlet.2009.07.051

${ }^{22}$ Z. F. Yan, D. H. Wang, X. L. He, W. X. Wang, H. X. Zhang, P. Dong, C. H. Li, Y. L. Li, J. Zhou, Z. Liu, L. Y. Sun, Deformation behaviors and cyclic strength assessment of AZ31B magnesium alloy based on steady ratcheting effect, Materials Science and Engineering: A, 723 (2018), 212-220, doi:10.1016/j.msea.2018.03.023

${ }^{23}$ H. B. Zhang, K. F. Zhang, S. S. Jiang, Z. Lu, The dynamic recrystallization evolution and kinetics of $\mathrm{Ni}-18.3 \mathrm{Cr}-6.4 \mathrm{Co}-5.9 \mathrm{~W}-$ 4Mo-2.19Al-1.16Ti superalloy during hot deformation, Journal of Materials Research, 30 (2015) 7, 1029-1041, doi:10.1557/jmr. 2015.78

${ }^{24}$ H. B. Zhang, K. B. Zhang, Z. Lu, C. H. Zhao, X. L. Yang, Hot deformation behavior and processing map of a $\gamma^{\prime}$-hardened nickelbased superalloy, Materials Science and Engineering: A, 604 (2015), 196-202, doi:10.1016/j.msea.2014.03.015

${ }^{25}$ D. F. Li, Q. M. Guo, S. L. Guo, H. J. Peng, Z. G. Wu, The microstructure evolution and nucleation mechanisms of dynamic recrystallization in hot-deformed Inconel 625 superalloy, Materials \& Design, 32 (2011) 2, 696-705, doi:10.1016/j.matdes.2010.07.040

${ }^{26}$ J. L. Gu, X. S. Wang, J. Bai, J. L. Ding, S. Williams, Y. C. Zhai, K. Liu, Deformation microstructures and strengthening mechanisms for the wire+arc additively manufactured Al-Mg4.5Mn alloy with inter-layer rolling, Materials Science and Engineering: A, 712 (2018), 292-301, doi:10.1016/j.msea.2017.11.113 